\title{
IDENTIFICATION AND BIOLOGICAL CHARACTERIZATION OF ISOLATES WITH ACTIVITY INHIBITIVE AGAINST Macrophomina phaseolina (Tassi) Goid.
}

\author{
Sandra Gacitúa A. ${ }^{\text {, }}$ Carolina Valiente F. ${ }^{1}$, Katy Díaz P. ${ }^{1}$, José Hernández C. ${ }^{1}$, Matilde Uribe M. ${ }^{1}$, and \\ Eugenio Sanfuentes V. 1* $^{*}$
}

\begin{abstract}
The Macrophomina phaseolina (Tassi) Goid fungus, causal agent of charcoal root rot, is considered one of the most important pathogens in forest nurseries. Recent studies in Chile have verified the antagonistic capacity of diverse bacterial isolates against M. phaseolina in vitro as well as in field testing. The objectives of this study were to identify Bacillus isolates and establish the mechanisms of antagonism against M.phaseolina. Isolates were identified with the bioMérieux biochemical kit. Tests were done in vitro and consisted in determining the production of volatile metabolites, siderophores, and the effect of different culture temperatures $\left(20,25,30\right.$, and $\left.35^{\circ} \mathrm{C}\right)$ on the production of diffusible metabolites and inhibition of mycelial growth of the pathogen. The isolates were identified as Bacillus subtilis IX 007, B. amyloliquefaciens VII 015 and VIII 016, B. pumilus IX 030, and B. stearothermophilus TM 008. It was not possible to identify the (-) Gram VI 009 isolate. At all the evaluated temperatures, isolates inhibited $M$. phaseolina, reaching $75 \%$ reduction of mycelial growth (B. subtilis IX 007 at $25{ }^{\circ} \mathrm{C}$ ). Some isolates showed volatile metabolites and siderophore production as possible mechanisms of antagonism.
\end{abstract}

Key words: biocontrol, Bacillus, Pinus radiata, forest nursery.

\section{INTRODUCTION}

The Macrophomina phaseolina (Tassi) Goid. fungus is the causal agent of charcoal root rot, a worldwide pathology affecting agricultural and forest crops (Shaner et al., 1999), with more than 500 susceptible hosts (Wyllie et al., 1984). The pathogen was detected in Chile in 1983 in Pinus radiata D. Don nurseries in the Bío-Bío Region (Butin and Peredo, 1986), and since then, has been detected in numerous nurseries converting it into an important sanitary problem. In the last few years, dissemination of the pathogen has been detected from the nurseries to the plantations through asymptomatic plants. Mortality has been observed in the first years of the plantation when there are predisposing conditions such as hydraulic stress of the plants and high soil temperatures (Barnard, 1994).

M. phaseolina is an optional saprophyte that survives in the soil thanks to micro-sclerotinia formation which are pseudoparenchymal tissue masses resistant to adverse environmental conditions (Shaner et al., 1999). Infection

${ }^{1}$ Universidad de Concepción, Facultad de Ciencias Forestales, Victoria 631, Concepción, Chile. "Corresponding author (esanfuen@udec.cl).

Received: 16 August 2008.

Accepted: 05 December 2008. is initiated when the root drippings of susceptible plants come into contact with micro-sclerotinias that remain latent in the soil, allowing their germination and subsequent penetration in the plant (Smith et al., 1989; Kendig et al., 2000). The observed symptoms in the root system are the blackening of the distal portion of the main root and lateral roots over which swelled zones appear that make them reach diameters two or three times higher than normal. Symptoms in the aerial part usually cannot be observed in initial states of infection. However, in more advanced states, progressive destruction of the root system provokes plants to present growth detention or loss, chlorosis, withering, or death (Smith et al., 1989; Shaner et al., 1999).

After the death of the plant, the micro-sclerotinias are incorporated into the soil through the plant tissue litter in decomposition where they can be viable for more than 3 years. Micro-sclerotinias in the soil and plant waste constitute the greatest source of M. phaseolina inoculum to cause new infections (Smith et al., 1989; Kendig et al., 2000; Baird et al., 2003).

The most successful control strategy used for charcoal root rot in forest nurseries has been soil fumigation with methyl bromide (Barnard, 1994). However, there are a 
series of problems with applying this product such as high cost, environmental pollution, breaking up the ecological balance of the soil, as well as the destruction of the ozone layer (Duniway, 2002; González, 2006). For these reasons, its use is prohibited in Europe and the United States, and will be prohibited in developing countries in 2015 according to the Montreal Protocol (Karliner, 1997).

Biological control has been considered as an alternative to control this disease since it is a highly selective method lasting over time (Nico et al., 2005). Numerous researches have been focused on searching and selecting antagonist microorganisms on diverse soil pathogens. Among the most used are bacterias like Bacillus, Pseudomonas, and Streptomyces, fungi of the Trichoderma, Penicillium, Gliocladium, Aspergillus, Rhizopus genera. These microorganisms, natural inhabitants of diverse substrates, in laboratory tests (in vitro) as well as in the greenhouse and field, have demonstrated antagonistic activity on a wideranging group of pathogens such as Sclerotium rolfsii, S. cepivorum, Rhizoctonia solani, Pythium ultimum, Phytophthora parasitica, and M. phaseolina (Bell et al., 1982; Balasundaram and Sarbhoy, 1988; Harrison and Stewart 1988; Hussain et al., 1990; Adekunle et al., 2001; Singh et al., 2008).

Unlike other pathogens, research is scarce demonstrating the effect of Bacillus bacteria to control M. phaseolina (Alippi and Mónaco, 1994). Among the possible biocontrol mechanisms in bacteria, antibiosis, competition, siderophores, and induction of systemic resistance are described (Devendra and Bhavdish, 2008). Antagonists can have various modes of action and this multiplicity is an important characteristic for their selection as biological control agents (Fernández-Larrea, 2000).

Bacillus isolates are known to synthesize a vast number of peptides with antibacterial and antifungal activity (Silva et al., 1997). Some studies indicate the presence of substances of the volatile and diffusible antibiotic type such as subtiline and iturins that inhibit pathogen growth (Szczech and Shoda, 2006). Another characteristic of the Bacillus species is that it has endospores that allow them to survive in extreme temperature conditions, desiccation, $\mathrm{pH}$, pesticides, fertilizers, and storage time (Backman et al., 1997).

Recent research conducted in the Laboratorio de Patología Forestal of the Universidad de Concepción, the effectiveness of some Bacillus and Pseudomonas isolates to control M. phaseolina was ascertained. The bacteria were evaluated by in vitro assays and then in nurseries with natural infestation of the pathogen, confirming the potential of some Bacillus isolates to reduce plant mortality of $P$. radiata. Among 568 bacterial isolates tested in vitro, $19.8 \%$ inhibited M. phaseolina mycelial growth. In assays carried out in $P$. radiata nurseries in the 2003-2004 and 2004-2005 seasons, Bacillus VII 015, VIII 016, IX 030, TM 008, IX 007, and VI 009 isolates significantly reduced plant mortality attributable to $M$. phaseolina (Valiente et al., 2008).

Given the potential of these isolates in the control of M. phaseolina, the objectives of this study were to identify the Bacillus isolates at the species level that have previously demonstrated potential as biocontrollers of $M$. phaseolina, and determine mechanisms of antagonism that could be related to the control of charcoal root rot.

\section{MATERIALS AND METHODS}

\section{Pathogenic fungal isolate}

All assays were with the M. phaseolina UDC-019 strain, isolated from the $P$. radiata root seedlings with symptoms of charcoal root rot were collected from a commercial nursery ("Carlos Douglas" of Forestal Mininco, Yumbel, Bío-Bío Region). The strain was stored in an agar-papa-dextrose culture medium (APD, Difco) in a bioclimatic chamber at $4{ }^{\circ} \mathrm{C}$ (Valiente et al., 2008). From storage, it was detached to new Petri dishes with APD culture medium, and was incubated in a culture chamber at $30^{\circ} \mathrm{C}$, for 4 days.

\section{Bacterial isolates}

Bacillus VII 015, IX 030, TM 008, VIII 016, IX 007, and VI 009 (Table 1) were selected for their capacity to control $M$. phaseolina ascertained in in vitro and field assays (Valiente et al., 2008). Strains were isolated from P. radiata and Eucalyptus globulus Labill. asymptomatic plant rhyzosphere and rhizoplane collected in different forest nurseries. Subsequently, they were stored at $-20{ }^{\circ} \mathrm{C}$ in $2 \mathrm{~mL}$ vials with dimethyl sulfoxide (DMSO) at $5 \%$, and multiplied in Petri dishes with APD culture medium and were incubated in a culture chamber at $24{ }^{\circ} \mathrm{C}$ for $24 \mathrm{~h}$.

\section{Identification of Bacillus spp. isolates at the species level}

Bacterial isolates were identified by means of a biochemical kit API 50CH (bioMérieux, Marcy L'Etoile, France) in combination with API 50CHB/E (bioMérieux) medium. API $50 \mathrm{CH}$ is a standardized system made up of 50 biochemical tests that allow identifying the metabolism type of carbohydrates in bacteria. API $50 \mathrm{CHB} / \mathrm{E}$ medium is a solution made up of $2 \mathrm{~g}$ ammonium sulphate; 0.5 $\mathrm{g}$ yeast extract; $1 \mathrm{~g}$ tryptone; $3.22 \mathrm{~g}$ disodic phosphate; $0.12 \mathrm{~g}$ monopotassic phosphate; $10 \mathrm{~mL}$ oligoelement solution; $0.17 \mathrm{~g}$ phenol red; demineralized water; $\mathrm{pH}$ 7.47.8 with a known cloudy pattern of $1 \times 10^{6} \mathrm{CFU} \mathrm{mL}^{-1}$ called "MacFarland". Colonies of pure bacteria from the dishes were transferred to a tube containing $2 \mathrm{~mL}$ sterile distilled water (SDW), forming a bacterial suspension 
Table 1. Origin of Bacillus spp. isolates identified and tested for biological characterization.

\begin{tabular}{llcl}
\hline Isolate & \multicolumn{1}{c}{ Locality (Region) ${ }^{\mathbf{1}}$} & Geographiccal coordinates & Species \\
\hline VII 015 & Constitución (Maule Region) & $35^{\circ} 19^{\prime} \mathrm{S} ; 72^{\circ} 24^{\prime} \mathrm{W}$ & Pinus radiata \\
IX 030 & Melipilla (Metropolitan Region) & $33^{\circ} 41^{\prime} \mathrm{S} ; 71^{\circ} 12^{\prime} \mathrm{W}$ & Eucalyptus globulus \\
TM 008 & Yumbel (Bío Bío Region) & $37^{\circ} 07^{\prime} \mathrm{S} ; 71^{\circ} 28^{\prime} \mathrm{W}$ & Pinus radiata \\
VIII 016 & Los Ángeles (Bío Bío Region) & $36^{\circ} 56^{\prime} \mathrm{S} ; 72^{\circ} 21^{\prime} \mathrm{W}$ & Eucalyptus globulus \\
IX 007 & Casablanca (Valparaíso Region) & $33^{\circ} 19^{\prime} \mathrm{S} ; 71^{\circ} 24^{\prime} \mathrm{W}$ & Eucalyptus globulus \\
VI 009 & Yumbel (Bío Bío Region) & $37^{\circ} 07^{\prime} \mathrm{S} ; 71^{\circ} 28^{\prime} \mathrm{W}$ & Pinus radiata \\
\hline
\end{tabular}

${ }^{1}$ Altitude: 0-300 m.a.s.1.

Table 2. Identification of Bacillus spp. isolate species by means of API $50 \mathrm{CH}$ biochemical test (bioMérieux, France).

\begin{tabular}{llc}
\hline Isolate identification & \multicolumn{1}{c}{ Species } & Similarity $^{1}$ \\
\hline & & $\%$ \\
IX 007 & B. subtilis & 72.6 \\
VII 015 & B.amyloliquefaciens & 92.0 \\
IX 030 & B.pumilus & 99.0 \\
VIII 016 & B.amyloliquefaciens & 82.7 \\
TM 008 & B. stearothermophilus & 99.7 \\
VI 009 & Unidentified & 00.0
\end{tabular}

${ }^{1}$ Identification at the species level is assigned as an acceptable profile with a percentage similarity greater than $75 \%$.

until reaching cloudiness equal to the MacFarland pattern. Then, API $50 \mathrm{CHB} / \mathrm{E}$ was inoculated with the bacterial suspension under study and was incubated at $24{ }^{\circ} \mathrm{C}$ for 24 $\mathrm{h}$. During this period, fermentation led to a change of color from phenol red to yellow in the medium, interpreted as a (+) reaction; when no change of color was observed, or was very weak, a (-) reaction was recorded. Results were analyzed with the V 3.0 identification program (bioMérieux, Marcy L'Etoile, France).

\section{Volatile organic compound production}

The method described by Mariano (1993) was used to determine the effect of liberated volatile metabolites for each bacterial isolate. Petri dish bottoms were arranged by twos, both containing APD medium, forming a closed chamber. A disc with a $1 \mathrm{~cm}$ diameter was placed in the center of the bottom dish with mycelia from the pathogen taken from the colony edge of a 4-day culture growing in APD at $28{ }^{\circ} \mathrm{C}$. On the top dish, $20 \mu \mathrm{L}$ of bacterial

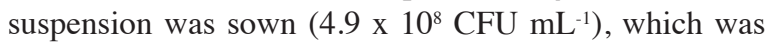
collected from a liquid R2A (Difco, Agar) culture medium, growing for $26 \mathrm{~h}$ at $28{ }^{\circ} \mathrm{C}$. Then the dish bottom edges were fitted one with the other and sealed with Parafilm (American National Can Company, Chicago Illinois, USA). ADE replaced bacterial suspension in the control. The assay was carried out at $24^{\circ} \mathrm{C}$ and maintained until the growth of the pathogen in the control reached the edge of the dish, then the M. phaseolina growth area was measured and the percentage of inhibition calculated according to the following formula:

$\%$ inhibition $=\left[1-\left(\frac{\begin{array}{c}\text { M.phaseolina } \text { area confronted } \\ \text { with each isolate }\end{array}}{\text { control M. phaseolina } \text { area }}\right)\right] * 100$

\section{Production at different temperatures of diffusible metabolites in the medium}

Temperatures were set at $20,25,30$, and $35{ }^{\circ} \mathrm{C}$ to determine occurrence and degree of inhibition of the pathogen for each bacterial isolate. In the center of a Petri dish containing APD, a $1 \mathrm{~cm}$ diameter disc was placed with pathogen mycelia, taken from the colony edge of a 4-day culture (APD). Two filter paper discs, imbibed with $20 \mu \mathrm{L}$ of bacterial suspension $\left(4.9 \times 10^{8}\right.$ $\mathrm{CFU} \mathrm{mL} \mathrm{m}^{-1}$ ), were immediately placed at a distance of $3 \mathrm{~cm}$ from the pathogen disc. Sterile distilled water was added to the control dishes. When the pathogen had completely grown in the control dish, the assay was stopped and each temperature level evaluated. Mycelial growth area of the pathogen colony was evaluated and the percentage of inhibition calculated in the same way as in the volatile metabolite assay.

\section{Siderophore detection}

Siderophore detection was carried out by means of a colorimetry assay containing a complex ternary called azurol S (CAS)/Fe (III)/hexadecyltrimethylammonium 
bromide, a universal medium for detecting siderophores. Siderophore production was determined with CAS agar according to the methodology described by Schwyn and Neilands (1987). Once the medium gelled, bacterial isolates were sown and incubated at $24{ }^{\circ} \mathrm{C}$ for 2 weeks. The evaluation was qualitative with observations on change of color in the medium. In this method, iron dyes the solid medium with a bluish color, so when the siderophores are excreted as the bacteria consume the iron; they produce a change in color shown as orange halos around the colonies in the blue agar, thus indicating the presence of siderophores.

\section{Experimental design}

Assays of the production of volatile organic compounds and diffusible metabolites at different temperatures were carried out following a completely randomized design with four replicates. In the first assay, the experimental unit corresponded to the pairs of Petri dishes with APD, and results were analyzed with ANOVA as well as the minimum significant difference test (MSD, level of significance $\alpha=0.05$ ). In the second assay, the experimental unit corresponded to the Petri dish. Results were analyzed with ANOVA and the Tukey multiple comparison test (level of significance $\alpha=0.05$ ). Analyses were carried out with SAS version 9.0.

\section{RESULTS AND DISCUSSION}

\section{Identification of Bacillus spp. isolates at the species level}

Five species of Bacillus were identified; four with a high percentage of similarity according to the profile pattern or database of the bioMérieux identification program V 3.0. Identification at the species level is considered acceptable with a percentage of similarity greater than $75 \%$. Likewise, the IX 007 isolate presented a relatively low level of similarity $(72.6 \%)$ (Table 2).

Among the identified bacteria, $B$. subtilis, $B$. amyloliquefaciens, and B. pumilus have a background of being biological control agents against diverse soil pathogens (Yu et al., 2002; Szczech and Shoda, 2006; El-Hassan and Gowen, 2006; Liu et al., 2008). Actual background information indicates that $B$. stearotermophilus is considered as a rhizobacterium which promotes root growth in E. globulus stakes (Díaz et al., 2008).

Various B. subtilis isolates are recorded for the control of diseases caused by phytopathogenic fungi (Schisler $e t$ al., 2004). In sugar beet (Beta vulgaris L.) and tomato (Lycopersicon esculentum Mill.), the application of $B$. subtilis GB03 reduces incidence of $R$. solani, Pythium sp., and other pathogens, as well as stimulating plant germination, growth and yield (Raupach y Kloepper, 1998). They also have the capacity to colonize plant roots, since $B$. subtilis GB03 is considered as plant growth promoting rhizobacterium (PGPR) (Turner and Backman, 1991). In the same way, the B. subtilis RB14 isolate is recorded and presents in vitro activity against various pathogens by producing antibiotics such as iturin A and surfactin, considered important factors in suppression of seedling damping-off caused by $R$. solani in tomato (Asaka and Shoda, 1996).

It has been determined that $B$. subtilis develops rapidly in culture medium and in nature, produces antibiotics, grows in a wide temperature range, and adapts to various environmental conditions. Furthermore, its metabolites are thermostable and, along with stability of the dehydrated antagonist substances, are important for its industrialization (Chen and $\mathrm{Wu}, 1999)$. It was determined that this species is capable of inhibiting growth in a wide range of fungal species (Wilhelm et al., 1998; Li et al., 1998) determining that the biocontrol mechanism is through antibiotic production (Chen and Wu, 1999). Furthermore, it is capable of inducing resistance by activating defensive genes in plants (Rauscher et al., 1999). This bacterium is also capable of stimulating plant growth due to the formation of substances with effects similar to those of cytoquine and auxine, as well as producing changes in the endogenous phytohormonal balance. This effect will allow the plant to tolerate pathogens, rapidly overcoming the critical states, and replacing the diseased portions of its roots (Killian et al., 2000).

Numerous studies have also been carried out with $B$. pumilus demonstrating its effectiveness as a biological control agent. B. pumilus (BSH-4 and ZB13), isolated from the rhizosphere of cucumber plants (Cucumis sativus L.), produced volatile anti fungi against Sclerotinia sclerotiorum and Botrytis cinerea, inducing morphological abnormalities, mycelial growth inhibition, and a decrease in sclerocia production in each pathogen under study (Liu et al., 2008). In tree species, B. pumilus QST 2808 demonstrated its control effect against various fungal parasites, and suppressed the organism that causes sudden oak death syndrome in oaks (Nothofagus obliqua (Mirb.) Blume (Fernández and Juncosa, 2003).

B. amyloliquefaciens isolates also have a potential as biological control agents as evidenced in diverse studies. B. amyloliquefaciens B94 suppressed R. solani and other plant pathogenic fungi, probably by means of antibiotic production (Yu and Sinclair, 1996). The $B$. amyloliquefaciens RC-2 isolate demonstrated inhibitive activity against the anthracnosis caused by Colletotrichum dematium in white mulberry foliage (Morus alba L.) due to fungal compounds (Hiradate et al., 2002), and $B$. 
amyloliquefaciens $2 \mathrm{TOE}$ reduced the severity of the gray mold caused by Botrytis cinerea in pears (Pyrus communis L.), as a result of competition for nutrients (Mari et al., 1996).

Among the isolates of this species, B.amyloliquefaciens FZB42 is perhaps the most studied as regards its mechanisms of action and effects, given that its genomic analysis has revealed its potential use as biocontroller of plant pathogens (Chen et al., 2009). Among the principal characteristics that allow controlling pathogens is the synthesis of lipopeptides and polyketides with antifungal activity such as surfactin and bacilomicine (Chen et al., 2009).

\section{Volatile organic compound production}

Five of the assayed isolates significantly reduced M. phaseolina mycelial growth by means of volatile metabolites (Figure 1). Inhibition of $M$. phaseolina mycelial growth fluctuated between 4 and $44 \%$ in the case of B. stearothermophilus TM 008 and B.amyloliquefaciens VIII 016, respectively.

It is generally convenient to distinguish between volatile inhibitive and/or diffusible metabolites in controlled laboratory conditions and those produced in the field. Results in vitro only indicate potential capacities and insofar as these will be expressed within each ecosystem, will be a function of the balance between production and metabolite loss, as well as the sensitivity of the microorganisms involved (Dal Bello et al., 1997). Diverse authors have held responsible the action of one or various volatile components produced by bacteria for the inhibition and destruction of pathogenic fungi mycelia (De La Fuente et al., 2001).

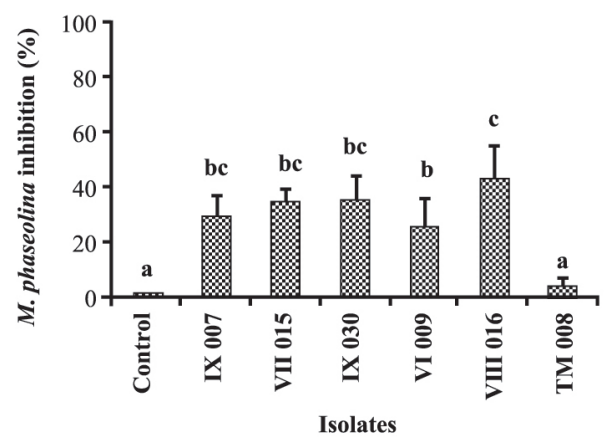

*Distinct letters over the columns indicate significant differences according to minimum significant difference test $(P=0.05)$. Values are means \pm standard deviation

Figure 1. Inhibition of mycelial growth of Macrophomina phaseolina by volatile organic compounds produced by Bacillus subtilis IX 007, B. amyloliquefaciens VII 015, B. pumilus IX 030, VI 009 isolate, B. amyloliquefaciens VIII 016, and B. stearothermophilus TM 008.
Production at different temperatures of diffusible metabolites in the medium

All the isolates under study inhibited M. phaseolina mycelial growth under the evaluated temperature ranges. Isolates that reached greater $M$. phaseolina inhibition were B. stearothermophilus TM 008, B. subtilis IX 007, B. amyloliquefaciens VII 015, and VIII 016. On the average, these isolates presented $60 \%$ inhibition; on the other hand, for $B$. pumilus IX 030 and VI 009, this effect was less than $30 \%$ (Figure 2).

As temperature increased, B. stearothermophilus TM 008, B. subtilis IX 007, B. amyloliquefaciens VII 015, and VIII 016 maintained their effectiveness between 50 and $60 \%$ to control M. phaseolina, except at $30{ }^{\circ} \mathrm{C}$ where these isolates decreased their inhibitive capacity. This could be explained owing to the fact that, under certain temperature conditions, these isolates generally sporulate rapidly and persist as spores without producing antibiotics (Shoda, 2000). Likewise, optimal growth of M. phaseolina in culture mediums occurs between 30 and $37{ }^{\circ} \mathrm{C}$ with a strong reduction over $40{ }^{\circ} \mathrm{C}$ (Dhingra and Sinclair, 1978).

According to the results, B. subtilis IX 007, B. stearothermophilus TM 008, and B. amyloliquefaciens VII 015 presented a greater antagonistic capacity against $M$. phaseolina in the different evaluated temperature levels.

Some researchers propose that biocontrol agents and their mechanisms is complex, their action varying with pathogen type and host plant. Temperature, soil type, $\mathrm{pH}$, humidity content, and action of other microflora components have an influence over them. It is probable that what is defined as biocontrol is a result of the action of a number of mechanisms working synergetically

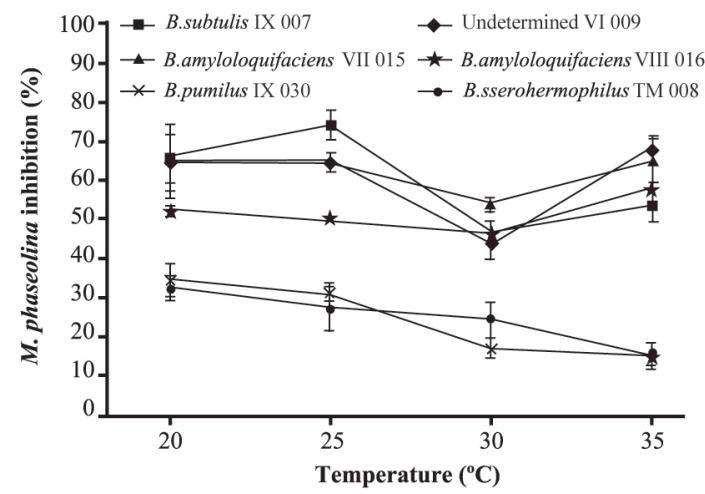

Figure 2. Inhibition of mycelial growth of Macrophomina phaseolina produced by Bacillus subtilis IX 007, B. amyloliquefaciens VII 015, B. pumilus IX 030, strain VI 009 strain, B. amyloliquefaciens VIII 016, and $B$. stearothermophilus TM 008 at different incubation temperatures. 
through the joint action of various antagonists, since not all antagonism mechanisms are present in a single agent. On the other hand, coevaluation of antagonistic and pathogenic organisms has determined that agents with proven biocontrolling activity do not show antagonism to other species, and even result inactive in the presence of the same pathogen when it originates from a different culture. Therefore, a new antagonist selection process would be necessary for each pathogen-host combination (Handelsman and Stabb, 1996; Howell, 2003, Monte and Llobell, 2003).

\section{Siderophore detections}

Siderophore production was not detected in B. pumilus IX 030 and B. amyloliquefaciens VIII 016 while, in the rest, presence of these iron kelant agents was evidenced by a change in color of the medium.

There is evidence that siderophores fulfill an active role in the inhibition of a microorganism with another. A parent strain of Pseudomonas fluorescens producing siderophore increased the emergence of cotton seedlings (Gossypium herbaceum L.) in a soil infested with Pythium ultimum as compared to a P. fluorescens mutant strain (Loper, 1988). This mutant siderophore was similar to the parent strain with respect to the prevention of seed colonization by P. ultimum. Thus, Loper (1988) concluded that while cotton seed colonization by $P$. fluorescens plays an important function in protecting the initial seed germination, siderophore production by bacteria is more important as an inhibition mechanism of $P$. ultimum during the emergence of the seedlings.

Sandy sites have a low nutrient retention capacity, among them $\mathrm{Fe}, \mathrm{N}, \mathrm{P}$, and $\mathrm{S}$ which are pulled out of the reach of the roots because of irrigation and rainwater. Plants are not seen as being affected by $\mathrm{Fe}$ sequestration on the part of the bacteria, given that most plants are capable of producing their own siderophores to capture iron, thus improving their own nutrition (O'Sullivan and O’Gara, 1992).

\section{CONCLUSIONS}

Isolates belonging to the $B$. subtilis, B. pumilus, $B$. stearothermophilus, and $B$. amyloliquefaciens species were identified as potential biocontrollers of $M$. phaseolina which present a background of biological control of diverse plant pathogens. Production of volatile organic compounds was one of the mechanisms associated with the inhibition of mycelial growth of M. phaseolina, emphasizing the effectiveness of a $B$. amyloliquefaciens isolate.

The magnitude of the antibiosis caused by the bacterial isolates against $M$. phaseolina varies as a function of temperature. All the isolates induced inhibition of $M$. phaseolina mycelial growth in the 20 to $35^{\circ} \mathrm{C}$ temperature range. Some isolates also presented siderophore production as a potential antagonism mechanism against M. phaseolina which could inhibit the growth of this pathogen in soil conditions with low $\mathrm{Fe}$ availability.

\section{RESUMEN}

Identificación y caracterización biológica de cepas de bacillus con actividad inhibitoria contra Macrophomina phaseolina (Tassi) Goid. El hongo Macrophomina phaseolina (Tassi) Goid., agente causal de la pudrición carbonosa de la raíz, es considerado uno de los patógenos más importantes en viveros forestales. Estudios recientes realizados en Chile comprobaron la capacidad antagónica de diversas cepas bacterianas contra M. phaseolina, tanto en ensayos in vitro como de campo. Los objetivos de este estudio fueron identificar las cepas de Bacillus y establecer los mecanismos de antagonismo contra M. phaseolina. La identificación de las cepas se realizó mediante kit bioquímico bioMérieux. Los ensayos fueron realizados in vitro y consistieron en determinar la producción de metabolitos volátiles, sideróforos y el efecto de diferentes temperaturas de cultivo $(20,25$, 30 y $35^{\circ} \mathrm{C}$ ) en la producción de metabolitos difusibles e inhibición del crecimiento micelial del patógeno. Las cepas fueron identificadas como Bacillus subtilis IX 007, B. amyloliquefaciens VII 015 y VIII 016, B. pumilus IX 030 y B. stearothermophilus TM 008. No fue posible la identificación de la cepa Gram (-) VI 009. En todas las temperaturas ensayadas, las cepas inhibieron $M$. phaseolina, alcanzando hasta $75 \%$ de reducción del crecimiento micelial (B. subtilis IX 007 a $25^{\circ} \mathrm{C}$ ). Las cepas mostraron como mecanismos de antagonismo la producción de metabolitos volátiles y de sideróforos.

Palabras clave: control biológico, Bacillus, Pinus radiata, viveros forestales.

\section{LITERATURE CITED}

Adekunle, A., K. Cardwell, D. Florini, and T. Ikotum. 2001. Seed treatment with Trichoderma species for control of damping-off of cowpea caused by Macrophomina phaseolina. Biocontrol Sci. Technol. 11:449-457.

Alippi, J., y C. Mónaco. 1994. Antagonismo in vitro de especies de Bacillus contra Sclerotium rolfsii y Fusarim solani. Rev. Fac. Agron. (B. Aires) 70:91-95. Asaka, O., and M. Shoda. 1996. Biocontrol of Rhizoctonia solani damping-off of tomato with Bacillus subtilis RB14. Appl. Environ. Microbiol. 62:4081-4085. 
Backman, P.A., M.A. Wilson, and J.F. Murphy. 1997. Bacteria for biological control of plant diseases. Environmentally safe approaches to crop disease control. p. 95-109. Lewis Publishers, New York, USA.

Baird, R.E., C. Watson, and M. Scruggs. 2003. Relative longevity of Macrophomina phaseolina and associated mycobiota on residual soybean roots in soil. Plant Dis. 87:563-566.

Balasundaran, V., and A. Sarbhoy. 1988. Inhibition of plant pathogenic fungi by Rhizobium japonicum. Indian Phytopathol. 41:128-130.

Barnard, E.L. 1994. Nursery-to-field carryover and postoutplanting impact of Macrophomina phaseolina on loblolly pine on a cutover forest site in North Central Florida. Tree Planter's Notes 45:68-71.

Bell, D., K. Wells, and H. Markham, C.R. 1982. In vitro antagonism of Trichoderma species against six fungal plant pathogens. Phytopathology 72:379-382.

Butin, H., y H.L. Peredo. 1986. Hongos parásitos en coníferas de América del sur con especial referencia a Chile. 100 p. J. Cramer, Berlin, Alemania.

Chen, X., A. Koumoutsi, R. Scholz, K. Schneider, J. Vater, R. Süssmuth, et al. 2009. Genome analysis of Bacillus amyloliquefaciens FZB42 reveals its potential for biocontrol of plant pathogens. J. Biotechnol. 140:2737.

Chen, T.W., and W.S. Wu. 1999. Biological control of carrot black rot. J. Phytopathol. 147:99-104.

Dal Bello, G.M., C.I. Mónaco, y A.R. Cháves. 1997. Efecto de los metabolitos volátiles de Trichoderma hamatum sobre el crecimiento de hongos fitopatógenos procedentes del suelo. Argentina. Rev. Iberoam. Micol. 14:131-134.

De la Fuente, L., N. Bajsa, P. Bagnasco, L. Quagliotto, L. Thomashow, and A. Arias. 2001. Antibiotic production by Pseudomonas fluorescens isolated from forage legume rhizosphere. J. Appl. Microbiol. 90:421-429.

Devendra, K., and N. Bhavdish. 2008. Interactions of Bacillus spp. and plants with special reference to induced systemic resistance (ISR). Microbiol. Res. In press.

Dhingra, O.D., and J.B. Sinclair. 1978. Biology and pathology of Macrophomina phaseolina. $166 \mathrm{p}$. Imprensa Universitaria da Universidad Federal de Viçosa, Viçosa, Mato Grosso, Brasil.

Díaz, K., C. Valiente, M. Martínez, M. Castillo, and E. Sanfuentes. 2008. Root-promoting rhizobacteria in Eucalyptus globulus cuttings. World J. Microbiol. Biotechnol. 25:867-873. doi: 10.1007/s11274-0099961-1.

Duniway, J.M. 2002. Status of chemical alternatives to methyl bromide for pre-plant fumigation of soil. Phytopathology 92:1337-1343.
El-Hassan, S.A., and S.R. Gowen. 2006. Formulation and delivery of the bacterial antagonist Bacillus subtilis for management of lentil vascular wilt caused by Fusarium oxysporum f. sp. lentis. J. Phytopathol. 154:148-155.

Fernández, C., y R. Juncosa. 2003. Biopesticidas. Revista Future Eco No 141.p. 14-19.

Fernández-Larrea, O. 2000. Microorganismos antagonistas para el control fitosanitario. Manejo Integrado de Plagas 62:96-100.

González, S. 2006. Bromuro de metilo: un fumigante en retirada. Colección Libros INIA No 20.173 p. Instituto de Investigaciones Agropecuarias, Santiago, Chile.

Handelsman, J., and E. Stabb. 1996. Biocontrol of soilborne plant pathogens. The Plant Cell 8:18551869.

Harrison, Y.A., and A. Stewart. 1988. Selection of fungal antagonists for biological control of onion white rot in New Zealand. N.Z. J. Exp. Agric. 16:249-256.

Hiradate, S., S. Yoshida, H. Sugie, H. Yada, and Y. Fujii. 2002. Mulberry anthracnose antagonists (iturins) produced by Bacillus amyloliquefaciens RC-2. Phytochemistry 61:693-698.

Howell, C.R. 2003. Mechanisms employed by Trichoderma species in the biological control of plant diseases: the history and evolution of current concepts. Plant Dis. 87:4-10.

Hussain, S., A. Ghaffar, and M. Aslam. 1990. Biological control of Macrophomina phaseolina charcoal root rot of sunflower and mungbean. J. Phytopathol. 30:157160.

Karliner, J. 1997. The barons of bromide: The corporate forces behind toxic poisoning and ozone depletion. The Ecologist 27:90-98.

Kendig, S.R., J. Rupe, and H. Scott. 2000. Effect of irrigation and soil water stress on densities of Macrophomina phaseolina in soil and roots of two soybean cultivars. Plant Dis. 84:895-900.

Killian, M., U. Steiner, B. Krebs, H. Junge, G. Schmiedeknecht, and R. Hain. 2000. FZB24 Bacillus subtilis- mode of action of a microbial agent enhancing plant vitality. Pflanzenschutz-Nachrichten Bayer p. 73-93.

Li, H., D. White, A. Lamza, F. Berger and C. Leifert. 1998. Biological control of Botrytis, Phytophthora and Pythium by Bacillus subtilis Cot1 and CL27 of micropropagated plants in high-humidity fogging glasshouses. Plant Cell Tiss. Organ Cult. 52: 109112.

Liu, W., W. Mu, B. Zhu, Y. Du, and F. Liu. 2008. Antagonistic activities of volatiles from four strains of Bacillus spp. and Paenibacillus spp. against soil-borne plant pathogens. Agric. Sci. (China) 7:1104-1114. 
Loper, J.E. 1988. Role of fluorescent siderophore production in biological control of Pythium ultimum by a Pseudomonas fluorescens strain. Phytopathology 78:166-72.

Mari,M., M. Guizzardi, and G.C.Pratella.1996. Biological control of gray mold in pears by antagonistic bacteria. Biol. Control 7:30-37.

Mariano, R.L. 1993. Métodos de seleção in vitro para o control e microbiológico de patógenos de plantas. Revisão Anual de Patología de Plantas 1:369-409.

Monte, E., and A. Llobell. 2003. Trichoderma in organic agriculture.p. 725-733. In V World Avocado Congress, Málaga, Spain. 19-24 October.

Nico, A.I., C. Mónaco, G. Dal Bello, y H. Alippi. 2005. Efectos de la adición de enmiendas orgánicas al suelo sobre la capacidad patogénica de Rhizoctonia solana. II. Microflora asociada y antagonismo in vitro de los aislados más frecuentes. RIA 34:29-44.

O'Sullivan, D.J., and F. O'Gara. 1992. Traits of fluorescent Pseudomonas spp. involved in suppression of plant root pathogens. Microbiol. Rev. 56:662-576.

Rauscher, M., A. Adam, L. Wirtz, S. Guggenheim, R. Mendgen, and K. Deising. 1999. PR-1 protein inhibits the differentiation of rust infection hyphae in leaves of acquired resistant erfgbbroad bean. Plant J. 19:625633.

Raupach, G.S., and J.W. Kloepper. 1998. Mixtures of plants growth-promoting rhizobacteria enhance biological control of multiple cucumber pathogens. Phytopathol. 88:1158-1164.

Schisler, D.A., J.P. Slininger, W.R. Behle, and A.M. Jackson. 2004. Formulation of Bacillus spp. for biological control of plant diseases. Phytopathol. 94:1267-1271.

Schwyn, B., and J. Neilands. 1987. Universal chemical assay for the detection and determination of siderophores. Anal. Biochem. 160:47-56.

Shaner, G., S. Abney, and D. Scott. 1999. Charcoal rot of soybeans. Purdue University. Department of Botany and Plant Pathology. W. Lafayette. Available at http://www.lgseeds.com/LG_Tech2/resources/ charcoalrotPU.pdf (accessed October 2009).

Shoda, M. 2000. Bacterial control of plant diseases, J. Biosci. Bioeng. 89:515-521.
Silva, C., L. Ciampi, y L. Burzio. 1997. Caracterización preliminar de un metabolito de Bacillus sp. con actividad antibiótica. In VI Congreso Nacional de Fitopatología, Talca. Resúmenes. Simiente 67:68-95.

Singh, N.,P. Pandey, R. Dubey, and D. Maheshwari. 2008. Biological control of root rot fungus Macrophomina phaseolina and growth enhancement of Pinus roxburghii (Sarg.) by rhizosphere competent Bacillus subtilis BN1. World J. Microbiol. Biotechnol. 24:1669-1679. doi: 10.1007/s11274-008-9680-z

Smith, R.S., C.S. Hodges, and C.E. Cordell. 1989. Charcoal root rot and black root rot. In Cordell, C.E., R.L.Anderson, W.H.Hoffard, T.D. Landis, R.S. Smith, and T. Harvey (eds.) Forest nursery pest. Agriculture Handbook 680. p. 112-113. U.S. Department of Agriculture, Forest Service, Washington D.C., USA.

Szczech, M., and M. Shoda. 2006. The effect of mode of application of Bacillus subtilis RB14-C on its efficacy as a biocontrol agent against Rhizoctonia solani. J. Phytopathol. 154:370-377.

Turner, J.T., and P.A. Backman. 1991. Factors relating to peanut yield increases after seed treatment with Bacillus subtilis. Plant Dis. 75:347-353.

Valiente, C., K. Díaz, S. Gacitúa, M. Martínez, and E. Sanfuentes. 2008. Control of charcoal root rot in Pinus radiata nurseries with antagonistic bacteria. World $\mathrm{J}$. Microbiol. Biotechnol. 24:557-568.

Wilhelm, E., A. Wolfgang, R. Schafleitner1, and B. Krebs. 1998. Bacillus subtilis an endophyte of chestnut (Castanea sativa) as antagonist against chestnut blight (Cryphonectria parasitica). Plant Cell Tiss. Organ Cult. 52:105-108.

Wyllie, T., S. Gangopadhyay, W. Teague, and R. Blanchar. 1984. Germination and production of Macrophomina phaseolina microsclerotia as affected by oxygen and carbon dioxide concentration. Plant Soil 81:195-201.

Yu, G.Y., and J.B. Sinclair. 1996. Evaluation of Bacillus amyloliquefaciens B94 for control of Rhizoctonia seedling disease on soybeans. (Abstr.) Phytopathology 86 (suppl.):S54.

Yu, G.Y., J.B. Sinclair, G.L. Hartman, and B.L. Bertagnolli. 2002. Production of iturin A by Bacillus amyloliquefaciens suppresing Rhizoctonia solani. Soil Biol. Biochem. 34:955-963. 